\title{
Dental eruption sequence and hypsodonty index of a Pleistocene macraucheniid from the Brazilian Intertropical Region
}

\author{
Leonardo Souza Lobo, ${ }^{1,2}$ Gisele Lessa, ${ }^{3}$ Cástor Cartelle, ${ }^{4}$ and Pedro S. R. Romano ${ }^{3}$ \\ ${ }^{1}$ Programa de Pós-Graduação em Biologia Animal, Universidade Federal de Viçosa. Avenida Peter Henry Rolfs, 36570-900, Viçosa, MG, Brazil \\ 〈leoloboo@gmail.com〉 \\ ${ }^{2}$ Current address: Laboratório de Processamento de Imagem Digital, Museu Nacional, Universidade Federal do Rio de Janeiro. Quinta da Boa \\ Vista, São Cristóvão, 20940-040, Rio de Janeiro, RJ, Brazil \\ ${ }_{3}^{3}$ Departamento de Biologia Animal, Universidade Federal de Viçosa. Avenida Peter Henry Rolfs, 36570-900, Viçosa, MG, Brazil \\ 〈gislessa@yahoo.com.br〉; 〈psrromano@gmail.com〉 \\ ${ }^{4}$ Pontifícia Universidade Católica de Minas Gerais (PUC Minas). Avenida Dom José Gaspar, 290 Coração Eucarístico, 30535-610, Belo \\ Horizonte, Minas Gerais, Brazil 〈cartelle@pucminas.br〉
}

\begin{abstract}
Litopterna is represented in the Pleistocene of the Brazilian Intertropical Region by a monospecific genus of Macraucheniidae, Xenorhinotherium. Although most of the knowledge about this family is derived from the dentition, some dental features still remain unknown. This study describes the eruption sequence of permanent dentition and classifies the hypsodonty status of $X$. bahiense. The specimens studied are from Toca dos Ossos, a limestone cave located in Bahia State. We perform qualitative macroscopic analysis to describe the eruption dental sequence. Additionally, we perform quantitative analysis to determine the hypsodonty index. The dental eruption sequence of the juvenile specimen is M1, M2, I1, I2, M3, I3, P1, P2, P3, and P4. In addition, the analysis of tooth wear in adult specimens provides similar results. The hypsodonty index assigns a mesodont tooth crown for $X$. bahiense. The dental eruption sequence is most similar to a rapid-growth extant mammal. Moreover, our results do not support afrotherian-like delayed dental eruption to Litopterna. The hypsodonty index can be related to data on vegetation of the Brazilian Intertropical Region and the shape of the premaxilla of $X$. bahiense, both of which suggest a browsing diet for this macraucheniid.
\end{abstract}

\section{Introduction}

With 15 genera, Macraucheniidae Gervais, 1855 is one of the two more diverse and representative families of the order Litopterna, which is recorded from the late Eocene to Late Pleistocene-Early Holocene (Bond et al., 1999; Schmidt and Ferrero, 2014). This order is part of the group called South American native ungulates (SANU) (Cifelli, 1985; Bond, 1999). Macraucheniidae includes middle- to large-sized herbivores and is considered a family more conservative in dental and postcranial aspects than Proterotheriidae because of its complete dentition without diastema and the presence of three digits (Paula-Couto, 1979; Bond, 1999). Moreover, the lineage of macraucheniids is characterized mainly by gradual retraction of the nasals and the backward shift of the nostrils, which reaches the maximum in Pleistocene taxa (Bond, 1999; Cartelle, 1999). Records of macraucheniids in the Pleistocene are widely distributed throughout South America. In the Pleistocene, three monospecific genera are currently valid: Macrauchenia Owen, 1838; Macraucheniopsis Paula-Couto, 1945; and Xenorhinotherium Cartelle and Lessa, 1988 (Bond, 1999; Schmidt and Ferrero, 2014). The genus Xenorhinotherium, the focus of this study, occurred in Late Pleistocene-early Holocene. Its record is mainly in the Brazilian Intertropical Region (BIR), and it has also been recorded in Mato Grosso State and Venezuela, but these two occurrences of $X$. bahiense need to be revised (Cartelle and Lessa, 1988; Cartelle, 1999; Salles et al., 2006; Socorro, 2006). Moreover, we do not agree with the nomenclatural action by Guérin and Faure (2004), which assigned $X$. bahiense Cartelle and Lessa, 1988 as a junior synonym of Macrauchenia patachonica Owen, 1838. First, Guérin and Faure (2004) did not compare their sample from caves in Piauí State with the type material of $X$. bahiense. Second, Guérin and Faure (2004) did not contest any diagnostic features of $X$. bahiense as originally assigned by Cartelle and Lessa (1988). Instead, Guérin and Faure (2004) deemed the observed variation between $X$. bahiense and $M$. patachonica species-level variation without properly testing such an assumption. Indeed, other studies (e.g., Scherer et al., 2009) do not follow the taxonomic arrangement of Guérin and Faure (2004), and further phylogenetic studies of Schmidt and Ferrero (2014) and Forasiepi et al. (2016) refuted the idea by revealing consistent morphological features that differ between the two monospecific genera.

Initially, the BIR paleogeographic region of $X$. bahiense occurrence was defined as characterized by dry forests, Cerrado and Caatinga ecosystems (sensu Cartelle, 1999). However, with input of new information from palynological and carbon isotope data, the definition of BIR was refined as a mixed environment of Atlantic and dry tropical forest, with a latitudinal difference that influenced the vegetation structure (Werneck et al., 2011; Dantas et al., 2013). 
Tooth eruption sequence is a topic of important concern for the study of ungulates, extant and extinct, due to its use in phylogenetic reconstructions and description of life history (Smith, 2000). In fact, this topic brought to light a discussion of SANU's relationship with the high-level extant clades, in which Agnolin and Chimento (2011) claimed the close relationship of two SANU orders, Notoungulata and Astrapotheria, with Afrotheria. This hypothesis was based on their interpretation of three morphological characters: thoracolumbar vertebrae, late replacement of deciduous cheek teeth, and the presence of a fossa on astragalus. However, Billet and Martin (2011) and Kramarz and Bond (2014) examined material of three among the five SANU orders (Notoungulata, Astrapotheria, and Pyrotheria), and found no evidence to support an afrotherian-like delayed dental eruption in notoungulates, astrapotheres, and pyrotheres, contrary to the statement by Agnolin and Chimento (2011). Moreover, proteomic studies using collagen proteins to perform phylogenetic analysis suggested that SANU is within Laurasiatheria and closely related to Perissodactyla (Welker et al., 2015). Regarding the dental sequence of replacement for litopterns, the only data were provided by Bergqvist (2010), but they are restricted to the succession of the third and fourth premolars, and from Paleocene litopterns from Brazil.

The pattern of dental replacement may indicate whether the species lived and died on a fast or a slow time scale (Smith, 2000). However, the mammalian dentition also should provide other information by the classification of a tooth crown. This classification, at the hypsodonty level, could be determined by an index, expressing the ratio of tooth dimension (Janis, 1988). Nevertheless, the index of hypsodonty brings information about crown height, and, consequently, relates to mode of feeding. Its information has to be aligned with other aspects, such as habitat type and other morphological features, to provide insight about species diet (Damuth and Janis, 2011). Most characterizations of crown height in Macraucheniidae refer to Macrauchenia patachonica Owen, 1838, and, in a subjective way, are characterized as more hypsodont macraucheniid (Cifelli, 1985) or are just cited as hypsodont cheek teeth (Paula-Couto, 1979). Aside from these instances, there are no rigorous classifications for the tooth crowns of Pleistocene macracheniids (Paula-Couto, 1979; Cifelli, 1985). Consequently, the family needs a classification for phylogeny or morphological comparison, as is available for Protherotheriidae (Bond et al., 2001).

In the present study, we describe the eruption sequence of permanent upper dentition of the Pleistocene macraucheniid Xenorhinotherium bahiense using the juvenile paratype to evaluate if this species, a Late Pleistocene SANU, shows a delay on dental eruption. In addition, we determine the hypsodonty status of $X$. bahiense in order to clarify its ecological classification in the RIB biome, so providing information of this taxon to test hypotheses of relationship within the family.

\section{Materials and methods}

All the specimens analyzed came from Toca dos Ossos limestone cave, located at the municipally Ourolândia
(UTM 24K 275224, 8790872), Bahia State, Brazil. Cartelle and Lessa (1988) stated that the fossils were deposited at the cave during the Late Pleistocene to early Holocene.

Anatomical abbreviations. $-\mathrm{C}=$ upper canine; $\mathrm{d}=$ deciduous; $\mathrm{HI}=$ hypsodonty index; $\mathrm{I}=$ upper incisive; $\mathrm{P}, \mathrm{p}=$ upper and lower premolars, respectively; $\mathrm{M}, \mathrm{m}=$ upper and lower molars, respectively.

Repository and institutional abbreviation.-The material is housed in the MCL (Museu de Ciências Naturais da Pontifícia Universidade Católica de Minas Gerais, Belo Horizonte).

Description of eruption sequence.-The documentation of the dental ontogeny of $X$. bahiense is based on the juvenile paratype (MCL 2643), which has an upper jaw with nine deciduous teeth and 17 permanent teeth. We also analyzed eight jaws, three uppers (MCL 2644/01, 3546, 3549) and five lowers (MCL $3559,3560,3577,3658,3769$ ), of adult specimens, observing the wear stages of fully erupted permanent teeth in order to compare the sequence of replacement in the juvenile specimen.

Qualitative macroscopic analysis was performed in all teeth to describe their ontogeny, evaluating three features: eruption stage, development of tooth's root, and degree of wear. For the eruption stage, we assigned four stages: "not erupted" (with germ in its dental crypt); "erupting" (below alveolar margin); "erupting above alveolar margin"; and "fully erupted." For the development of the tooth root, we assigned three stages: "root fully opened" (with neck that may be delimited); "root start closing" (neck and roots are well delimited); and "root closed" (all roots fully formed and closed). For the degree of wear, we assigned five wear stages for each dentition that had been delimited by a combination of occlusal structure features, seen in upper (Fig. 1.1), and lower (Fig. 1.2) dentition. For upper teeth, the stages range from "no wear" (stage 1) to "extremely worn" (stage 5); when cusps are completely worn, they have straight mesial and distal margins, and mesiolabial fossette is vestigial or absent (Fig. 2). The three intermediate stages are: "little wear" (stage 2), when mesial and median structures are little worn but distal structures (metacone, metastyle) not are worn; "intermediate wear" (stage 3), when all cups and styles are worn and the mesial and distal cingulum are still present; "heavy worn" (stage 4), when the mesiolabial fossette is shallow, the mesial cingulum is absent, and the distal cingulum is vestigial or absent. For lower teeth, the stages range from "no wear" (stage 1) to "cuspids extremely worn out" (stage 5), when all structures are completely worn and forming a continuous flat surface (Fig. 2). The three intermediate stages are: "little wear" (stage 2), when the paralophid, protoconid, and metalophid (labial trigonid structures) are more worn than metaconid and all talonid structures; "intermediate wear" (stage 3), when trigonid structures show the same level of wear, the talonid structures are less worn than trigonid, and the metaconid and cristid oblique still are independent; "heavy wear" (stage 4), when the trigonid and talonid are deeply worn and join the metaconid and cristid obliquely.

Hypsodonty index.-For the classification of X. bahiense, we used the hypsodonty index (HI; Janis 1988), which is the ratio between height and width of tooth crown. This index is 
calculated only for third lower molars that do not exhibit excessive dental wear. Therefore, the $\mathrm{HI}$ in $X$. bahiense is based on five specimens (MCL 3558, 3772, 3776, 3795, 3839), which are classified in stages 1 and 2 . All the measurements are in millimeters (mm).
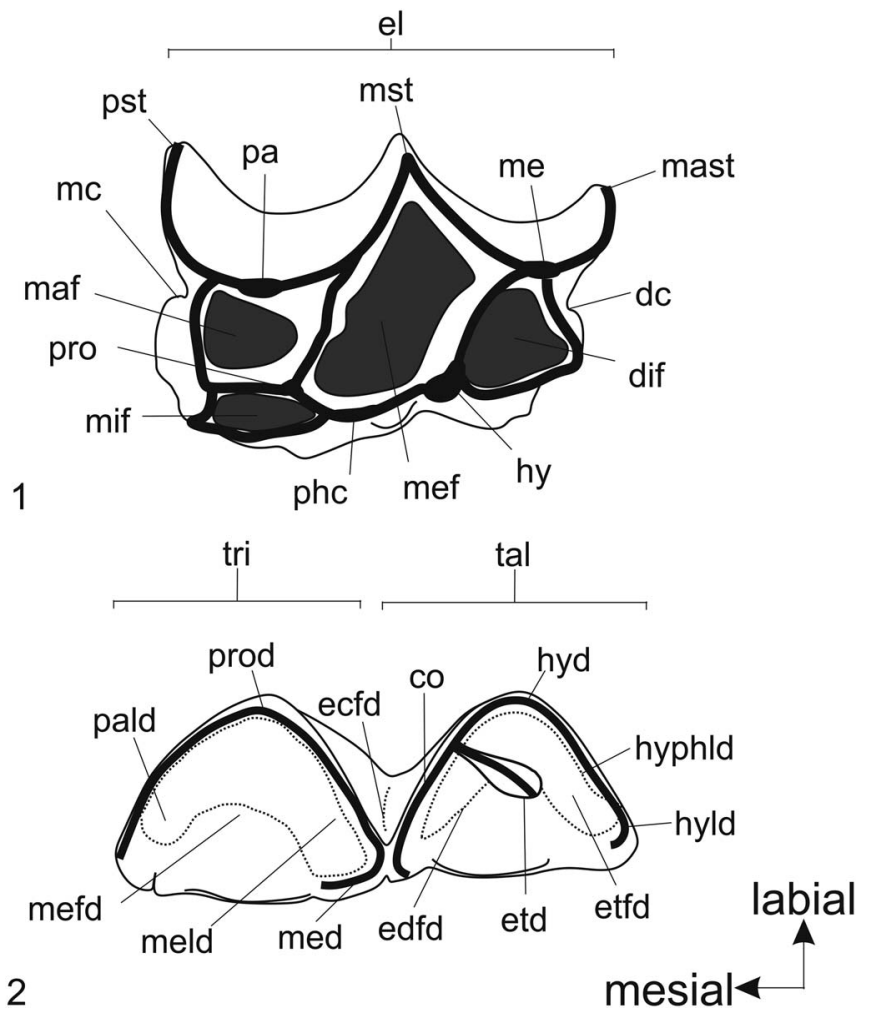

Figure 1. Structures of the cheek teeth of Xenorhinotherium bahiense. Abbreviations for upper cheek teeth (1): dc, distal cingulum; dif, distolingual fossette; el, ectoloph; hy, hypocone; maf, mesiolabial fossette; mast, metastyle; mc, mesial cingulum; me, metacone; mef, median fossette; mif, mesiolingual fossette; mst, mesostyle; pa, paracone; phc, protocone-hypocone crest; pro, protocone; pst, parastyle. Abbreviations for lower cheek teeth (2): co, cristid oblique; ecfd, ectoflexid; edfd, endoflexid; etd, entoconid; etfd, entoflexid; hyd, hypoconid; hyld, hypoconulid; hyphld, hypolophulid; med, metaconid; meld, metalophid; mefd, metaflexid; pald, paralophid; prod, protoconid; tal, talonid basin; tri, trigonid.

\section{Results}

Eruption sequence.-The dental remains of MCL 2643 (Xenorhinotherium bahiense paratype) are composed of two fragmented upper jaws with cheek teeth and 17 isolated teeth, adding up to 26 teeth belonging to this juvenile individual (Fig. 3). The right dentition contains $\mathrm{dP} 3-\mathrm{M} 3$ in a fragmentary upper jaw, and dI3-dC, dP2, I1-I3, and P2 isolated; also, the alveolar crypt of P3 and P4 is preserved. The left dentition contains $\mathrm{dP} 4-\mathrm{M} 3$ implanted in a fragmentary upper jaw, and $\mathrm{dP} 1-\mathrm{dP} 3, \mathrm{I} 1-\mathrm{I} 2$, and P2-P4 isolated, and the alveolar crypt of P4. The two sides of the paratype dentition exhibit the same dental features (Table 1). The two deciduous teeth exhibit distinct degrees of wear, with dP3 more worn than $\mathrm{dP} 4$. This makes it possible to determine that $\mathrm{dP} 3$ erupted before $\mathrm{dP} 4$. For the incisors, I1 and I2 exhibit roots in the same stage of development as the root of M2, which indicates that the I1 and I2 erupted before M3. All other premolars exhibited the same parameters examined, suggesting that all premolars erupted in a short period. Although there is a lack of information on permanent premolar eruption sequence, we obtained some information on the permanent eruption sequence through an analysis of deciduous premolars. The occlusal surfaces of the $\mathrm{dP} 1-\mathrm{dP} 3$ are completely worn, and even the $\mathrm{dP} 4$ is considerably worn, with occlusal structures still present and outlined by enamel (fossettes mesiolingual, median, and distolingual). This indicates that $\mathrm{dP} 1-\mathrm{dP} 3$ lost their function, whereas $\mathrm{dP} 4$ was still functional, therefore P1-P3 should have erupted before P4. Due to the absence of both $\mathrm{C}$, their positions in the replacement sequence cannot be assessed. Therefore, we assumed that the sequence of replacement of permanent dentition in this juvenile specimen was $\mathrm{M} 1>\mathrm{M} 2>\mathrm{I} 1>\mathrm{I} 2>\mathrm{M} 3>\mathrm{I} 3>\mathrm{P} 1>\mathrm{P} 2>\mathrm{P} 3>\mathrm{P} 4$.

The dentition of MCL 2644 (right and left) in the skull of the holotype has the right I1-M3 and left P1-M3 (Fig. 4.1). The only incongruence within the eruption sequence is that the $\mathrm{P} 4$ exhibit the same wear stage of M1. The sequence I1-C exhibits the same level of wear, with the paracone worn but still keeping its shape. Other upper dentitions of adult individuals, MCL 3546 and MCL 3549, were also examined (Fig. 4.2, 4.3). As observed for MCL 2644, the P4 were more worn than M3 in all adult specimens. MCL 3546, a specimen with teeth less worn

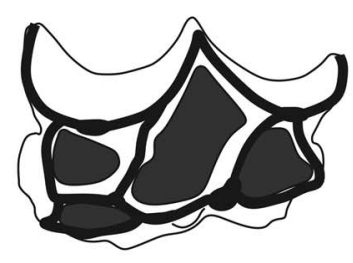

DEGREE 1
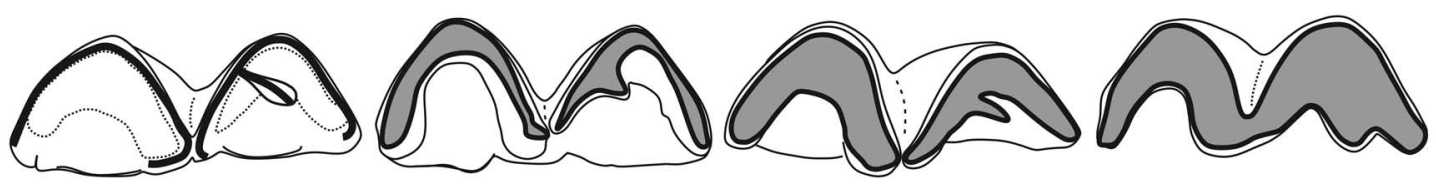

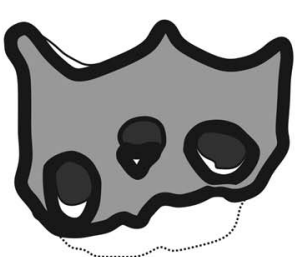

DEGREE 5

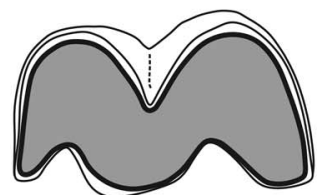

Figure 2. Wear degrees of Xenorhinotherium bahiense in upper (above) and lower (below) teeth. With wear progression, the enamel (highlighted in white) is worn and the dentine (highlighted in gray) is progressively exposed, whereas upper teeth fossettes (represented in black) become apparently smaller due to their conical shape until they disappear (see Figure 1 for structures identification). 


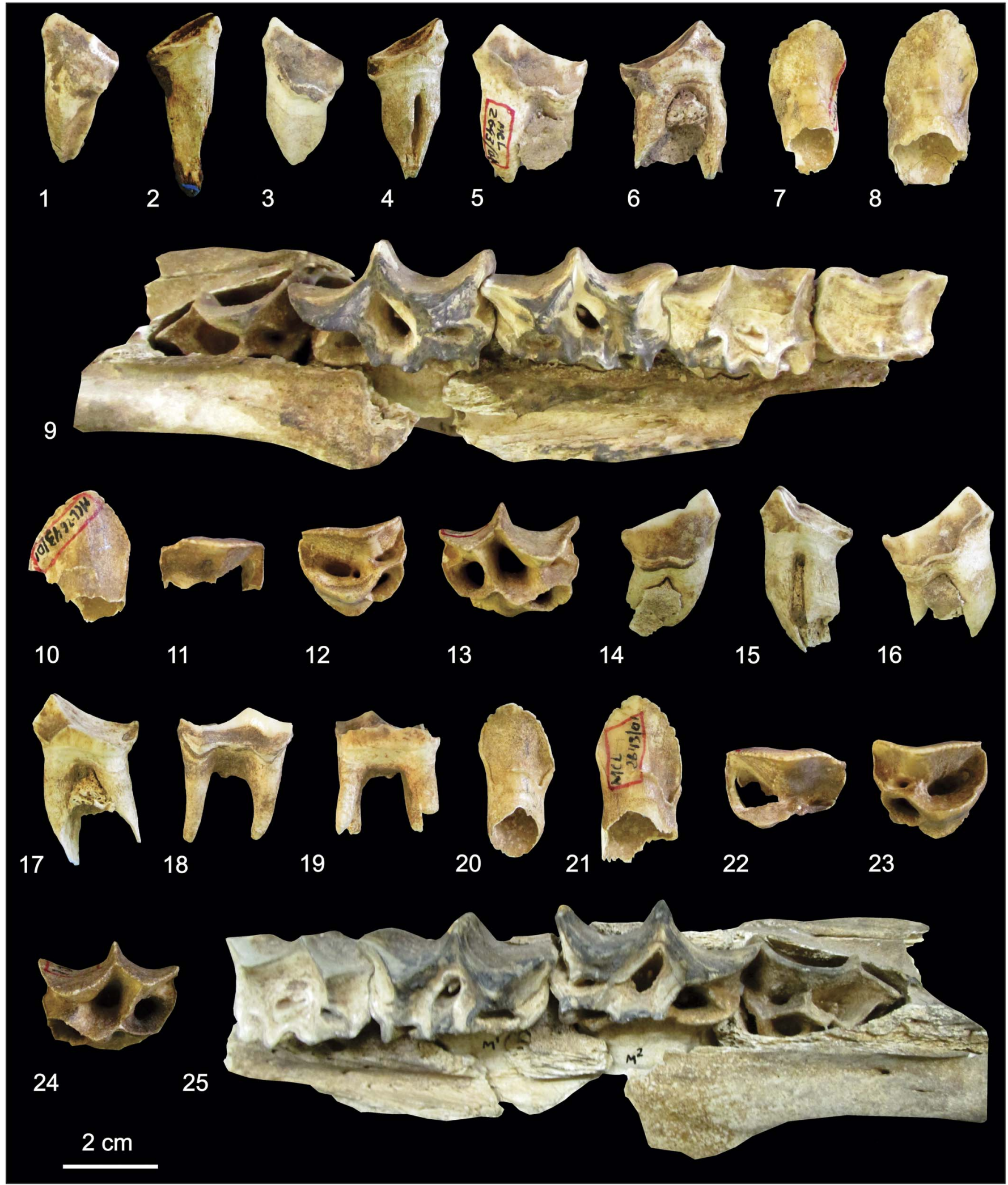

Figure 3. Upper dentition of juvenile specimen of Xenorhinotherium bahiense, with deciduous and permanent teeth (MCL 2643). (1-13), right teeth; third deciduous incisor, (1) labial and (2) lingual views; deciduous canine, (3) labial and (4), lingual views; second deciduous premolar, (5) labial and (6) lingual views; first permanent incisor, (7) lingual view; second permanent incisive, (8) lingual view; fragmentary right jaw with dP3-M3 implanted, (9) occlusal view; third permanent incisor, (10) lingual view; second permanent premolar, (11) occlusal view; third permanent premolar, (12) occlusal view; fourth permanent premolar, (13) occlusal view; (14-25), left teeth; first deciduous premolar, (14) labial and (15) lingual views; second deciduous premolar, (16) labial and (17) lingual views; third deciduous premolar, (18) labial and (19) lingual views; first permanent incisor, (20) lingual view; second permanent incisor, (21) lingual view; second permanent premolar, (22) occlusal view; third permanent premolar, (23) occlusal view; fourth permanent premolar, (24) occlusal view; fragmentary left jaw with dP4-M3, (25) occlusal view. Scale bar $=2 \mathrm{~cm}$. 
Table 1. Development of each tooth from the specimen MCL 2643; $\mathrm{E}=$ eruption stage; $\mathrm{R}=$ root development; $\mathrm{W}=$ degree of wear; $-=$ missing data.

\begin{tabular}{llllllll}
\hline & \multicolumn{3}{c}{ Right } & & \multicolumn{3}{c}{ Left } \\
\cline { 2 - 4 } \cline { 6 - 7 } Side/Tooth & E & R & W & & E & R & W \\
\hline dI3 & 4 & 3 & 4 & - & - & - \\
dC & 4 & 3 & 4 & - & - & - \\
dP1 & - & - & - & 4 & 3 & 5 \\
dP2 & 4 & 3 & 5 & 4 & 3 & 5 \\
dP3 & 4 & 3 & 5 & 4 & 3 & 5 \\
dP4 & 4 & 3 & 4 & 4 & 3 & 4 \\
I1 & - & 2 & 1 & - & 2 & 1 \\
I2 & - & 2 & 1 & - & 2 & 1 \\
I3 & - & 1 & 1 & - & - & - \\
P2 & 1 & 1 & 1 & - & - & 1 \\
P3 & 1 & 1 & 1 & 1 & 1 & 1 \\
P4 & 4 & 3 & 1 & 1 & 1 & 1 \\
M1 & 3 & 2 & 3 & 4 & 3 & 3 \\
M2 & 2 & 1 & 1 & 3 & 2 & 2 \\
M3 & & & & & 2 & 1 & 1 \\
\hline
\end{tabular}

than in the other specimens, has P4 less worn than M1. This indicates that the wear stages are influenced by other factors besides the sequence eruption of the teeth.

MCL 3577 is a fragmented lower jaw with the dental sequence $\mathrm{p} 2-\mathrm{m} 3$ (Fig. 4.4). Even the $\mathrm{p} 2$ is less molarized than the other premolars in this specimen, and it is evident that $\mathrm{p} 2$ is less worn than the other premolars. That interpretation is supported by the wear on the protoconid, metaconid, and cristid oblique. Also, p4 is less worn than $\mathrm{m} 1$, which is supported by the wear on the metaconid. However, as in the upper dentition of analyzed adult specimens, $\mathrm{p} 4$ is more worn than $\mathrm{m} 3$, which is supported by the metaconid, and the talonid, which shows no wear on $\mathrm{m} 3$. Other specimens that have lower teeth studied are MCL 3559, MCL 3560, MCL 3658, and MCL 3769. All of them exhibit the same pattern as described for MCL 3577, but with less information because these specimens preserve fewer teeth.

Hypsodonty index.-The sample comprises two $\mathrm{m} 3$ with no wear (stage 1) and three $\mathrm{m} 3$ with little wear (stage 2) (Table 2). The mean of $\mathrm{m} 3$ with no wear is 2.24 ; the mean including the other three $\mathrm{m} 3$ (stage 2) is 2.04. Both results place X. bahiense close to the interval of 1.50-3.00, thus characterizing the species as having mesodont crowns.

\section{Discussion}

Eruption sequence.-The results indicate that $X$. bahiense has a sequence of replacement most similar to a rapid-growth mammal, with incisors and premolars erupting after the molars (Smith, 2000). The extant terrestrial ungulates with most similar sequence of replacement are the artiodactyls, specifically species of families Cervidae and Giraffidae, such as Cervus elaphus Linnaeus, 1758 and Okapia johnstoni (Sclater, 1901), respectively (Smith, 2000). On the other hand, the currently accepted phylogenetic hypotheses for placental mammals (Buckley, 2015; Welker et al., 2015) place SANU as more closely related to perissodactyls. This divergence between phylogenetic signal and dental eruption sequence suggests that an ecological pressure on this trait was possibly important during ungulate evolution, with some cases of adaptive convergence in dental eruption sequences (Smith, 2000).

Our results have only a single incongruence in wear sequence between juvenile and adult specimens. The wear stage of P4 differs from that expected for adult specimens. Therefore, the wear stage of P4 in adult X. bahiense (MCL 2644, MCL 3546) is greater than that of M3. However, the presence of the dental crypt in $\mathrm{P} 4$ and the stage of development of its root establish its placement in the eruption sequence. The incongruence observed in adult wear stage of $\mathrm{P} 4$ is probably due to the masticatory process, as suggested by Lessa (1992), in which $X$. bahiense has M3 less subject to wear than other cheek teeth. In addition, the angle of occlusion between the upper and lower jaws could cause this difference in wear rate among teeth that differ in positions (Spinage, 1971).

The only data about the permanent eruption sequence for Litopterna is provided by Bergqvist (2010) using species of the families Protolipternidae and Proterotheriidae: Protolipterna ellipsodontoide Cifelli, 1983 and Paranisolambda prodromus (Paula-Couto, 1952), respectively. Bergqvist's data provides information about the replacement sequence between the two posterior premolars (P3 and $\mathrm{P} 4)$ and the molar sequence. Although the data of $P$. ellipsodontoide and $P$. prodromus are incomplete, a clear distinction is observed between them and the sequence for $X$. bahiense: the P3 and P4 erupted before or almost at the same time as M3 (Bergqvist, 2010), whereas in $X$. bahiense $\mathrm{P} 3$ and $\mathrm{P} 4$ erupted after $\mathrm{M} 3$. Furthermore, in P. ellipsodontoide $\mathrm{P} 4$ erupted before $\mathrm{P} 3$. This is contrary to that observed for $X$. bahiense in our study and Phenacodontidae, a family of North American "archaic ungulates" closely related to Litopterna (West, 1981).

The "delayed dental eruption" has two concepts clarified by Billet and Martin (2011). Our focus here is on the concept of delayed eruption of permanent dentition relative to skull growth, which is regarded as a synapomorphy of Afrotheria (Asher and Lehmann, 2008). This delay of eruption occurs when one species spends well over half of its lifespan without a completely erupted permanent dentition (e.g., elephants, sea-crows, and hyraxes) (Asher and Lehmann, 2008). Although we do not consider cranial measurements in our sample, they explain, the absence of delayed dental eruption in the juvenile individual (MCL 2643). This is evident because this juvenile individual (MCL 2643) has already erupted most of its permanent dentition. Moreover, the juvenile does not show co-ossified epiphyses on the limb bones as completely ossified, and the fusion between radius and ulna had yet not begun (Cartelle and Lessa, 1988; Lessa, 1992). In summary, our results reinforce the observation that South American native ungulates (SANU) do not show delayed dental eruption, as previously suggested by Billet and Martin (2011) and Kramarz and Bond (2014) for other orders of SANU. This rejects the proposed diagnostic synapomorphy of SANU and Afrotheria by Agnolin and Chimento (2011).

The closest related litopterns in which the $\mathrm{HI}$ has been applied are species of the family Proterotheriidae. The sampled species show a pattern of increase of the HI during the diversification of the family in the Cenozoic (Bond et al., 2001). The HI in Proterotheriidae changes from brachyodont teeth in late Oligocene-middle Miocene species to mesodont 


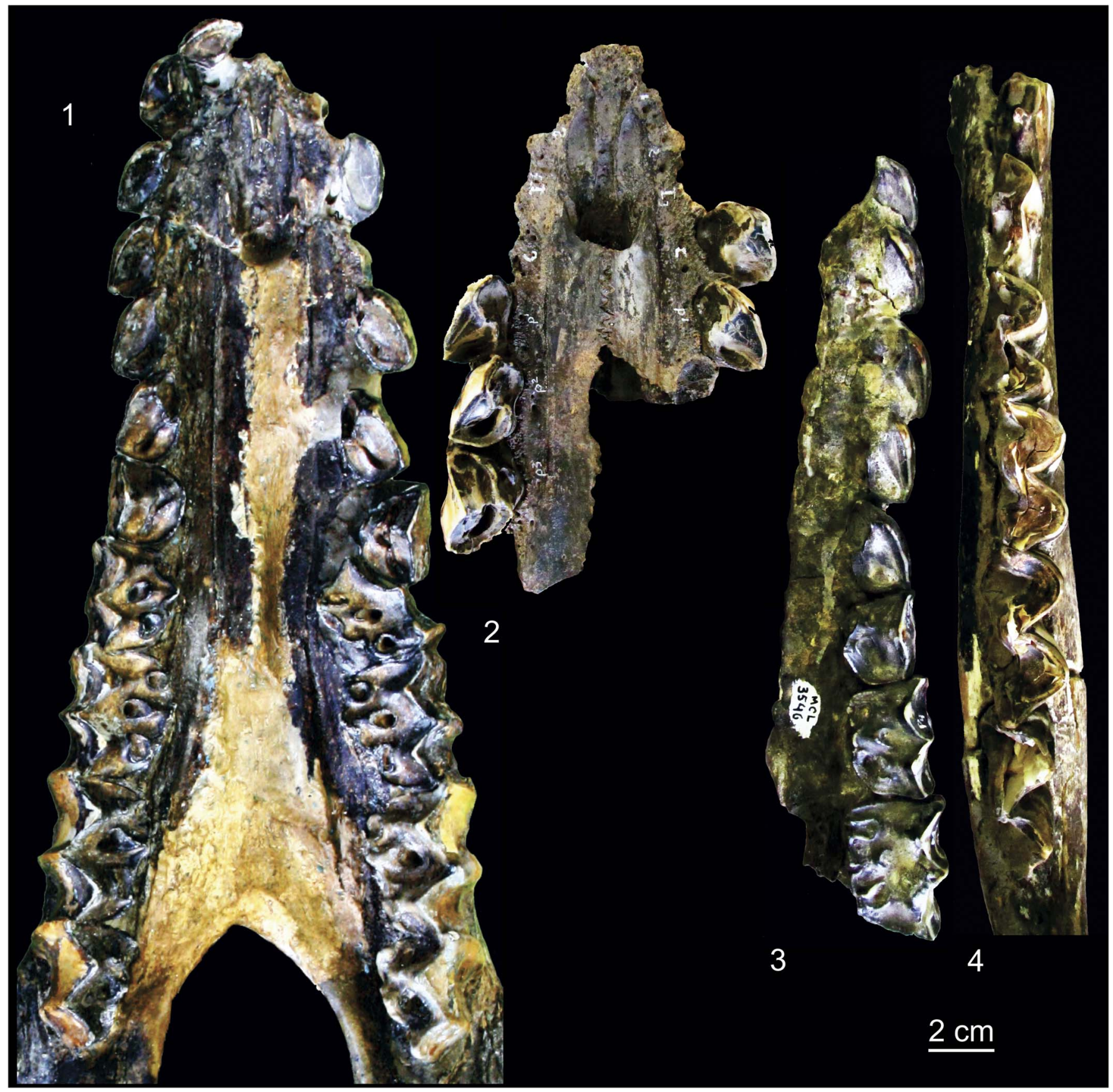

Figure 4. Dentition (occlusal view) of adult specimens of Xenorhinotherium bahiense. (1) MCL 2644; (2) MCL 3549; (3) MCL 3546; (4) MCL 3577. Scale bar $=2 \mathrm{~cm}$

teeth in late Miocene species, and reaches the highest value (2.00-2.50) in Pleistocene species with Neolicaphrium recens Frenguelli, 1921 (Bond et al., 2001). The best-known families of Litopterna, Macraucheniidae, and Protherotheriidae are represented by species with mesodont teeth in the Pleistocene (Bond, 1999).

Damuth and Janis (2011) reported that HI should only be interpreted by taking into account the habitat type, as the Brazilian Intertropical Region is considered a region in which Atlantic and dry forest vegetation could occur. Due to the variation in habitat type in RIB, we suggest that the environment occupied by $X$. bahiense includes woodland, an open forest where canopy is still mostly continuous but ground cover may include grass, forest, and a closed forest, with few or no clearings (Werneck et al., 2011; Dantas et al., 2013). Using this relation between $\mathrm{HI}$ and habitat type, $X$. bahiense has been characterized as a browser, with diet based on $\mathrm{C}_{3}$ plants, in both habitat types. This interpretation is different from the diet hypothesized for the other Late Pleistocene macraucheniid. Macrauchenia patachonica based on isotope analysis as a mixed feeder, with a diet based on plants $\mathrm{C}_{3}$ and $\mathrm{C}_{4}$ (Domingo et al., 2012). Additionally, Janis (1995) proposed that the shape of premaxilla could be useful as an indicator of diet in terrestrial herbivores. This observation corroborates our proposal for 
Table 2. Measurements of specimens for calculation of hypsodonty index $(\mathrm{HI})$

\begin{tabular}{lcccc}
\hline Specimen & Wear stage & Height & Width & HI \\
\hline MCL 3772 & 1 & 32.37 & 15.41 & 2.10 \\
MCL 3776 & 1 & 30.94 & 12.96 & 2.39 \\
MCL 3558 & 2 & 27.58 & 14.61 & 1.89 \\
MCL 3795 & 2 & 29.44 & 16.14 & 1.82 \\
MCL 3839 & 2 & 30.33 & 15.18 & 2.00 \\
\hline
\end{tabular}

differences in diet between $X$. bahiense and M. patachonica because both species show different premaxilla shapessharpened and straight, respectively (Cartelle and Lessa, 1988; Schmidt and Ferrero, 2014).

Future studies should focus on other litopterns, mainly Adianthidae and Proterotheriidae, families that are closely related with Macraucheniidae (Cifelli, 1985), to evaluate whether there is a common pattern of replacement sequence in monophyletic groups or whether there are multiple sequences during macraucheniid evolution, as in Artiodactyla and Perissodactyla (Smith, 2000). Furthermore, it is necessary to add more data about $\mathrm{HI}$ for Macraucheniidae in order to evaluate whether the increase in hypsodonty occurs with the diversification of the lineage, as in North American horses and probably in Proterotheriidae (Bond et al., 2001; Damuth and Janis, 2011). Additionally, data from other approaches (e.g., microwear and isotope analysis) are needed to make inferences concerning the paleoecology of Macraucheniidae.

\section{Acknowledgments}

We thank Conselho Nacional de Desenvolvimento Científico e Tecnológico (CNPq) for the financial grant and Universidade Federal de Viçosa for the physical support to develop this work (grants to G. Lessa). This paper includes part of the Master's thesis of L. Lobo and was supported by CAPES. A.M. Ribeiro (FZB/RS) was part of the thesis evaluating committee and provided important suggestions that improved the manuscript. L. Lobo also thanks CAPES for his current scholarship (PhD candidate). We thank G. Muricy (Museu Nacional/Universidade Federal do Rio de Janeiro) for his critical revision of earlier versions of the manuscript. We also thank M. Bond, a second anonymous reviewer, and the editors for suggestions and comments.

\section{References}

Agnolin, F.L., and Chimento, N.R., 2011, Afrotherian affinities for endemic South American "ungulates": Mammalian Biology, v. 76, p. 101-108. doi: 10.1016/j.mambio.2010.12.001

Asher, R.J., and Lehmann, T., 2008, Dental eruption in afrotherian mammals: BMC Biology, v. 6, p. 1-11. doi: 10.1186/1741-7007-6-14

Bergqvist, L.P., 2010, Deciduous premolars of Paleocene litopterns of São José de Itaboraí Basin, Rio de Janeiro, Brasil: Journal of Paleontology, v. 84, p. 858-867. doi: http://dx.doi.org/10.1666/09-084.1

Billet, G., and Martin, T., 2011, No evidence for an afrotherian-like delayed dental eruption in South American notoungulates: Naturwissenschaften, v. 98 , p. 509-517. doi: 10.1007/s00114-011-0795-y

Bond, M., 1999, Quaternary native ungulates of Southern South America-a synthesis, in Rabassa, J., and Salemme, M., eds., Quaternary Vertebrate Paleontology in South America: Quaternary of South America and Antarctic Peninsula, v. 12, p. 177-205.
Bond, M., Perea, D., Ubilla, M., and Tauber, A., 2001, Neolicaphrium recens Frenguelli, 1921, the only surviving Protherotheriidae (Litopterna, Mammalia) into the South American Pleistocene: Palaeovertebrata, v. 30, p. $37-50$.

Buckley, M., 2015, Ancient collagen reveals evolutionary history of the endemic South American 'ungulates': Proceedings of the Royal Society B: Biological Sciences, v. 282, p. 1-9. doi: http://dx.doi.org/10.1098/rspb. 2014.2671

Cartelle, C., 1999, Pleistocene mammals of the Cerrado and Caatinga of Brazil, in Eisenberg, J.F., and Redford, K.H., eds., Mammals of the Neotropic: the Central Neotropics: London, The University of Chicago Press, v. 3, p. 27-48.

Cartelle, C., and Lessa, G., 1988, Descrição de um novo gênero e espécie de Macraucheniidae (Mammalia, Litopterna) do Pleistoceno do Brasil: Paula-Coutiana, v. 3, p. 3-26.

Cifelli, R.L., 1983, The Origins and Affinities of the South American Condylarthra and Early Tertiary Litopterna (Mammalia): American Museum Novitates, v. 2772, p. 1-49.

Cifelli, R.L., 1985, South American ungulate evolution and extinction, in Stehli, F.G., and Webb, S.D., eds., The Great American Biotic Interchange, v. 3 : New York, Springer-Verlag, p. 249-266. doi: 10.1007/978-1-46849181-4_9

Damuth, J., and Janis, C.M., 2011, On the relationship between hypsodonty and feeding ecology in ungulate mammals, and its utility in palaeoecology: Biological Reviews, v. 86, p. 733-758. doi: 10.1111/j.1469-185X.2011. 00176.x

Dantas, M.A.T., Dutra, R.P., Cherkinsky, A., Fortier, D.C., Kamino, L.H.Y., Cozzuol, M.A., Ribeiro, A.S., and Vieira, F.S., 2013, Paleoecology and radiocarbon dating of the Pleistocene megafauna of the Brazilian Intertropical Region: Quaternary Research, v. 79, p. 61-65. doi: 10.1016/j. yqres.2012.09.006

Domingo, L., Prado, J.L., and Alberdi, M.T., 2012, The effect of paleoecology and paleobiogeography on stable isotopes of Quaternary mammals from South America: Quaternary Science Reviews, v. 55, p. 103-113. doi: 10.1016/j.quascirev.2012.08.017

Forasiepi, A.M., MacPhee, R.D.E., Del Pino, S.H., Schmidt, G.I., Amson, E., and Grohé, C., 2016, Exceptional skull of Huayqueriana (Mammalia, Litopterna, Macraucheniidae) from the late Miocene of Argentina: anatomy, systematics, and paleobiological implications: Bulletin of the American Museum of Natural History, v. 404, p. 1-76. doi: http://dx.doi.org/10.5531/ sd.sp. 23

Frenguelli, J., 1921, Sobre un proterotérido del Pampeano superior de Córdoba, Neolicaphrium recens, nov.: Actas de la Academia Nacional de Ciencias en Córdoba, v. 7, p. 7-23.

Gervais, P., 1855, Recherches sur les mamifères fossiles de l'Amérique du Sud, in Castelnau, F., ed., Expédition dans les parties centrales de l'Amerique du Sud, de Rio de Janeiro à Lima au Para; exécuté par ordre du Gouverment français pendant les annés 1843 à 1847 sous la direction du comte Francis de Castelnau: Zoologie, v. 7, p. 1-63.

Guérin, C., and Faure, M., 2004, Macrauchenia patachonica Owen (Mammalia, Litopterna) from the São Raimundo Nonato Archaeological Area (Piauí, North Eastern Brazil) and the diversity of the Pleistocene Macraucheniidae: Geobios, v. 37, p. 516-535. doi: 10.1016/j.geobios.2003.04.006

Janis, C.M., 1988, An estimation of tooth volume and hypsodonty indices in ungulate mammals, and the correlation of these factors with dietary preferences, in Russell, D.E., Santoro, J.P., and Sigogneau-Russell, D., eds., Teeth revisited: Proceedings of the VII ${ }^{\text {th }}$ International Symposium on Dental Morphology, Paris: Mémoires du Muséum National d'Histoire Naturelle, v. 53, p. 367-387.

Janis, C.M., 1995, Correlations between craniodental morphology and feeding behavior in ungulates: reciprocal illumination between living and fossil taxa, in Thomason, J., ed., Functional Morphology in Vertebrate Paleontology: Cambridge, Cambridge University Press, p. 76-98.

Kramarz, A., and Bond, M., 2014, Critical revision of the alleged delayed dental eruption in South American "ungulates": Mammalian Biology, v. 79, p. 170-175. doi: http://dx.doi.org/10.1016/j.mambio.2013.11.001

Lessa, G., 1992, Estudo descritivo de Xenorhinotherium bahiense Cartelle \& Lessa, 1988 e comparação com outras espécies de Macraucheniidae (Litopterna, Mammalia) [Master's thesis]: Rio de Janeiro, Universidade Federal do Rio de Janeiro, $264 \mathrm{p}$.

Linnaeus, C., 1758, Systema Naturae per Regna Tria Naturae: Secundum Classes, Ordines, Genera, Species, cum Characteribus, Differentiis, Synonymis, Locis, 10th ed., Stockholm, Laurentius Salvius, 824 p.

Owen, R., 1838, Fossil Mammalia, in Darwin, C.R., ed., Zoology of the Voyage of H.M.S. Beagle, under the command of Captain Fitzroy, during the years 1832 to 1836: London, Smith Elder \& Co., v. 1, p. 1-40.

Paula-Couto, C. de, 1945, Sobre un macrauquénido gigante Macraucheniopsis gen. nov. del Pampeano inferior de la Argentina: Notas del Museo de La Plata, v. 10, p. 233-257. 
Paula-Couto, C. de, 1952, Fossil mammals from the beginning of the Cenozoic in Brazil. Condylarthra, Litopterna, Xenungulata, and Astrapotheria: Bulletin of the American Museum of Natural History, v. 99, p. 355-394.

Paula-Couto, C. de, 1979, Tratado de Paleomastozoologia: Rio de Janeiro, Acadêmia Brasileira de Ciências, 590 p.

Salles, L.O., Cartelle, C., Guedes, P.G., Boggiani, P.C., Janoo, A., and Russo, C.A.M., 2006, Quarternary mammals from Serra da Bodoquena Mato Grosso do Sul, Brazil: Boletim do Museu Nacional, v. 521, p. 1-12.

Scherer, C.S., Pitana, V.G., and Ribeiro, A.M., 2009, Protherotheriidae and Macraucheniidae (Litopterna, Mammalia) from the Pleistocene of Rio Grande do Sul State, Brazil: Revista Brasileira de Paleontologia, v. 12, p. 231-246. doi: 10.4072/rbp.2009.3.06

Schmidt, G.I., and Ferrero, B.S., 2014, Taxonomic reinterpretation of Theosodon hystatus Cabrera and Kraglievich, 1931 (Litopterna, Macraucheniidae) and phylogenetic relationships of the family: Journal of Vertebrate Paleontology, v. 34, p. 1231-1238. doi: http//dx.doi.org/10.1080/02724 634.2014.837393

Sclater, P.L., 1901, On an apparently new species of zebra from the Semliki forest: Proceendings of the Zoological Society of London, v. 1, p. $50-52$.

Smith, B.H., 2000, 'Schultz's Rule' and the evolution of tooth emergence and replacement patterns in primates and ungulates, in Teadford, M.F., Smith,

M.M., and Ferguson, M.W., eds., Development, Function and Evolution of Teeth: Cambridge, Cambridge University Press, p. 212-228.
Socorro, O.A.A., 2006, Tesoros paleontológicos de Venezuela: el cuaternario del Estado Falcón: Caracas, Instituto del Patrimonio Cultura, 120 p.

Spinage, C.A., 1971, Generatodontology and horn growth of the impala (Aepyceros melampus): Journal of Zoology, v. 164, p. 209-225. doi: 10.1111/1.1469-7998.1971.tb01307.x

Welker, F., Collins, M.J., Thomas, J.A., Wadsley, M., Brace, S., Cappellini, E., Turvey, S.T., Reguero, M., Gelfo, J.N., Kramarz, A., Burger, J. Thomas-Oates, J., Asford, D.A., Ashton, P.D., Rowsell, K., Porter, D.M. Kessler, B., Fischer, R., Baessmann, C., Kaspar, S., Olsen, J.V., Kiley, P., Elliott, J.A., Kelstrup, C.D., Mullin, V., Hofreiter, M., Willerslev, E., Hublin, J., Orlando, L., Barnes, I., and MacPhee, R.D.E., 2015 Ancient proteins resolve the evolutionary history of Darwin's South American Ungulates: Nature, v. 522, p. 81-84. doi: 10.1038/nature 14249

Werneck, F.P., Costa, G.C., Colli, G.R., Prado, D.E., and Sites, J.W., Jr., 2011 Revisiting the historical distribution of Seasonally Dry Tropical Forest: new insights based on palaeodistribution modelling and palynological evidence: Global Ecology and Biogeography, v. 20, p. 272-288. doi: 10.1111/j.14668238.2010.00596.X

West, R.M., 1981, Deciduous dentition of the Early Tertiary Phenacodontidae (Condylarthra, Mammalia): American Museum Novitates, v. 2461, p. 1-37.

Accepted 31 May 2017 